\title{
Why Is Recreational Hunting a Moral Evil?
}

\author{
Anna Szklarska \\ (Pedagogical University of Cracow; anna.szklarska@up.krakow.pl) \\ ORCID: 0000-0003-4424-2143
}

\begin{abstract}
The paper reviews the recent book edited by Dorota Probucka, entitled The Ethical Condemnation of Hunting (in Polish: Etyczne potępienie myślistwa), Universitas Press, Kraków 2020, pp. 426. Probucka is one of the most prominent Polish experts in animal studies, especially in applied ethics and the field of animal rights (e.g., Probucka 2018a, 2018b, 2017). The discussed monograph encompasses the contributions of 19 authors representing 9 universities from Poland and abroad. Their core issue of consideration was the topical problem of hunting, examined from various perspectives: ethical and legal, psychological, social and cultural, both on the theoretical level and in relation to the practice of hunting. This review focuses on the core arguments against hunting and discusses them in detail.

The Ethics in Progress journal had the honour of contributing to the media patronage of Dorota Probucka's et al. edition.
\end{abstract}

Keywords: Hunting; recreational hunting; aggression; ethics; animal rights; Dorota Probucka's book The Ethical Condemnation of Hunting.

\section{Introduction: The Main Thesis and Purpose of the Monograph}

A critically valuable book has recently been published in Poland, edited by Professor Dorota Probucka (Pedagogical University of Cracow, Poland; the vice-president of the Polish Ethical Society) who for many years has been involved in the fight for animal rights in the field of education and legislation ${ }^{1}$. In 2017, she established the Academic Society Against Recreational Hunting. The book The Ethical Condemnation of Hunting contains 22 contributions of 19 authors from Poland and abroad, representing 9 universities and research centers.

There is a clear thesis in the book, namely that hunting as a hobby is a morally reprehensible practice. Its purposes are also sound: to discredit hunting practices and change social awareness, and to dispel the myths and misconceptions surrounding hunting. Many people are convinced that hunters care for nature, rationally supervise the so-called hunting management and only kill sick animals.

Hunters themselves pretend to be 'the guardians of animals' who help them survive

1 Article proofread by Stephen Dersley (ORCID:0000-0002-6765-8590) 
the winter, watch over the population size, and ensure the high genetic quality of forest and field species. They claim to eliminate the least adapted specimens that are not fast enough or alert enough to escape. This is a false message. During the hunt itself, hunters do not select animals in terms of their health condition, as do natural predators who only prey upon weaker individuals.

There is no general awareness of how much damage hunting causes. Such damage primarily includes: the animals wounded by gunshots, who then bleed in torment for extended periods (Korpikiewicz 2020, 51), the contamination of the natural environment with lead, the threat of rare species becoming extinct, and trauma among youth participating in hunting, not to mention their demoralization. It is all the more disgusting as the hunters are armed with the most modern weapons, with which they kill completely defenseless creatures. It has not been a match of equals for a long time. The hunters themselves objectify their victims, in order to move their deaths beyond the realm of emotions. One of the contributors to the book, Professor Honorata Korpikiewicz (Adam Mickiewicz University in Poznań, Poland), calls the falsified narrative about the honorable hunter who cares about the welfare of animals "the greatest myth that tries to give meaning to killing" (Korpikiewicz 2020, 49).

Professor Marcin Urbaniak (Pedagogical University of Cracow, Poland) interprets the Code of Hunting Ethics as a tool for masking violence, and also critically analyzes one of the hunting educative programs ("Hunters for children, children for animals"). Many similar examples of hunters' hypocrisy can be found in the book. Nevertheless, the

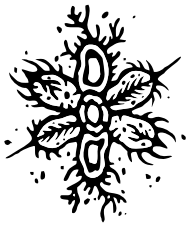
majority of the public do not approve of the deliberate killing of wild animals for one's own satisfaction and pleasure, rightly viewing such behavior as unethical. The arguments of hunting enthusiasts do not convince people. The question must therefore be asked: why do we accept the barbaric hobbies of the few that harm society as a whole?

\section{Approaching the Essence of Recreational Hunting (Sports and Hobby) and Ethical Arguments for Its Rejection}

By recreational hunting we mean hunting which is not necessary for survival. This means that the great majority of modern hunts fall into this category. As Dariusz Jedzok (Australian Animal Studies Association) notices: "The modern recreational hunter does not kill to survive, he is not guided by necessity. The death of an animal is still a desirable component of hunting, but its purpose is not to obtain food or hides; it is a specific side effect of the hunter's actions driven by the lust for thrills or trophies" (Jedzok 2020, 76). Hunters kill animals consciously, deliberately and for no good reason, often tormenting them, for example in the case of hunting with hounds and near fox holes. Most of the book's contributors believe that hunters engage in this pastime simply for perverse pleasure. It is necessary to demand a change in the mentality of people managing forest resources and the establishment of new standards: legal, moral and socio-cultural. The creator of the 
ethics of reverence for life, Albert Schweitzer, considered killing an animal as justifiable only in self-defence or in an extreme situation, although it is difficult to imagine nowadays a situation in which it would be the only way to obtain food in order to survive.

D. Probucka $(2020,23)$ suggests the category of "legally unpunished murder" as a synonym for hunting. She points to the bestiality and sophisticated cruelty of these practices. The aim of the monograph is not only to deepen the public awareness of the essence of hunting, but also to awaken the moral sensitivity of the largest possible group about the harm done to animals. The authors appeal to our consciences. They share the belief that animals, due to their having a similar susceptibility to pain, and because of the advantage humans have over them, should not experience suffering at their hands. People with a high level of moral sensitivity do not want to hurt anyone, not only people but also animals. After all, empathy concerns not only compassion, sacrifice and solidarity with the suffering fellow humans, but with every living being.

The message of the publication is as follows: a sense of solidarity in suffering with animals entails not limiting ourselves to refraining from inflicting suffering, but to be ready to fight in defence of suffering beings, to prevent their harm and mistreatment, and to demand punishment for their tormentors. Hunting cannot be justified neither in the utilitarian ethics of Jeremy Bentham and John Stuart Mill, nor in terms of David Hume's emotivism, nor in the light of Immanuel Kant's deontology, and even less in the ethics of reverence for life of Albert Schweitzer. Of course, we could extend this list with other names (e.g., Mahatma Gandhi), because it is difficult to justify inflicting suffering on a living being

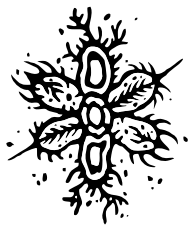
for the sake of entertainment or experiencing strong emotions. To the question "What would that bull you killed tell you?" a former hunter replied with disarming frankness: “He wouldn't tell me anything but cry, he would cry for me. He would cry for what I did to myself" (Kruczyński 2020, 401).

This statement is consistent with the basic assumptions of the ethics of Socrates, who taught that by inflicting suffering, harm, and committing wickedness, a person irreversibly and primarily violates himself, strikes a blow against his own humanity, dignity and rationality. The ban on adikein - doing harm, causing suffering is always in force, and no exceptions are allowed. On the basis of Socrates' ethics, it is better to take suffering on oneself, as long as it does not cause evil or harm. In Socrates' opinion, accepting loss is not a failure of the inner man; however, inflicting it on others means loss of the soul, its irreversible corruption. To inflict harm is the greatest evil (see Plato, Gorgias and Crito). Whoever does this is a miserable wretch who deserves pity (Plato, cf.).

On the other hand, a person who is capable of renouncing harm gains power over himself, over his complex of desires. Evil deeds destroy the soul and plunge it into an incurable disease. If a man indulges in harmful desires, he also destroys himself, therefore the bull crying over the hunter would react appropriately. Along with the development of moral consciousness, the scope of beings upon whom man must not inflict suffering is extending. 


\section{Responsibility for the Other and the World}

Already in the introduction, the editor of the monograph emphasizes that it is not true that little depends on the attitude of individual citizens. Each of us can change the law, the fairness of which is seriously questionable. In the book, we can find suggestions for specific legislative solutions, modelled on the example of various countries - in Germany, a ban on feeding forest animals was introduced, and in Costa Rica, Kenya and Colombia, a ban on commercial hunting. We also will find the appeal: "let us strive to eliminate hobby hunting, at the statutory level and by municipalities announcing their areas as huntingfree zones. Let us postulate introducing more civilized and humane solutions than killing animals with firearms" (Probucka 2020,14). Since their reproduction can be controlled by sterilization or contraception, these bloodless methods should be used.

\section{Hunting as Practicing Appetitive Aggression}

Many of the authors write directly about the primitive motivations of the hunters who try to present the real purpose of their practices in a veiled way, manipulating the public opinion. One thesis put forward in the book is that recreational hunting is a model example of appetitive aggression. As Andrzej Elżanowski (Warsaw University, Poland) explains, referring to the research of M. S. Wilson and E. Peden:

As opposed to reactive (expressive, impulsive) aggression, instrumental (proactive) aggression is calculated, planned action against someone for a specific goal. If this goal is gratification (joy, satisfaction) from violence and inflicting suffering, then such instrumental aggression, related to cruelty, is sometimes called appetitive aggression (after Elżanowski 2020, 63).

It is a catalyst for sadistic practices or organizing dog or cock fights. As Probucka observes: "This is what modern hunting is all about - practicing appetitive aggression based on the atavistic pleasure derived from inducing fear, suffering and death" (Probucka $2020,206)$. In the monograph, the psychological aspects of hunting are subjected to an extensive analysis. And so Dariusz Jedzok examined the cognitive dissonance of hunters evoked by taking an innocent life, the beauty and majesty of which seems delightful, but which does not stop them from annihilating it. The author also describes hunters' strategies for maintaining internal self-esteem in situations where there is tension resulting from the realization of the desire to kill another creature. In order to weaken this paralyzing - although completely natural - dissonance, the hunters assign a new meaning to the observed and hunted animals, giving them a new status. The same is true of people who keep chickens or pigs, when they must one day become their torturers, there is a spontaneous modification of roles and functions, and the perception of an animal is rapidly transformed.

The most common technique for this re-evaluation consists in the reclassification, 
or rather reification, of the animal. The purpose of these strategies is to suppress the feeling of being torn and inner contradiction. According to Jedzok, hunters conduct the aforementioned "reclassification of the victim in three ways: by elevating it to the rank of an equal opponent, by assigning it to a group of lower, less valuable entities, or by objectifying it" (Jedzok 2020, 79). The first strategy is particularly popular, because it allows for self-appreciation by making hunting an arena for sporting struggles, creating the illusion of an honourable fight in difficult and harsh conditions, imposed by nature itself. Hunters change the status of the victim by emphasizing the attributes of its masculinity, and those which show the cleverness, strength or bravery of the animal. "In this way, the victim becomes an enemy, the shooting of which is rationalized as a form of necessary defence" (Jedzok 2020, 79).

It is no coincidence that hunters are so eager to take pride in defeating large, stately males of a given species, which, incidentally, contradicts the narrative they put forward, namely that they target the weakest and most sickly individuals, acting for the good of the ecosystem and replacing predators. The data cited in the monograph show that the opposite is true: hunting leads to a significant decline in the size and reproductive age of many species. One should break the intricately woven web of misrepresentations related to hunting and honestly admit that "recreational hunting, which is often presented by the participants themselves as a sport or an equal fight, is in fact a form of unilateral aggression, an act of violence against an opponent who has not agreed to participate in the struggle" (Jedzok 2020, 82).

Ewa Czerwińska-Jakimiuk (Pedagogical University of Cracow, Kraków, Poland) discusses the psychological determinants of human violence against animals, including the techniques used by hunters to ethically neutralize a misdeed, which helps them to cope with their remorse. In order to soothe their conscience, it is necessary to use a psychological defence strategy, to falsify the proper sense of the actions. The source of the hunter's conduct may be simpler than we think. It may be a primal drive. According to Elżanowski, "the pleasure of killing and bullying is, like sex, our evolutionary heritage, which requires self-control. Such a heritage is also biophilia, which is positively associated as a motivation for pro-environmental attitudes, but turns out to be ethically ambivalent" (Elżanowski 2020, 172).

This is the case because the protection of entire species goes hand in hand with the ruthless treatment of individuals (especially the weakest ones) and even justifies it, in a way. As part of the human regulation of ecosystems, certain species are arbitrarily considered undesirable. Moreover, if moral progress was possible thanks to the even greater mastery of primal drives and instincts (for the benefit of reason), then the lack of control over the will to kill, the desire to channel aggression in the direct act of pursuing and catching the victim means regression. Elżanowski cites research that indicates the erotic excitement felt during hunting is rooted in an atavistic, primal instinct to relieve tension. The experience of this peculiar fascination is so strong that it can lead to a habit. 
Engaging in hunting is like an addiction, which is confirmed in the accounts of hunters and their families presented in the book. Describing this phenomenon, Elżanowski refers to the research of the anthropologist Matt Cartmill (Elżanowski 2020, 68). Hunters present their activities as realizing cultural heritage. However, they constitute a denial of culture and a return to barbaria.

\section{The Paradoxes of Hunting}

Dariusz Dąbek (Pedagogical University of Cracow, Poland) points out that one cannot admire nature and then exterminate it because of that admiration. This is an obvious error of reasoning. As the philosopher emphasizes, "killing, which is a consequence of hunting, is not communing with nature" (Dąbek 2020, 94).

Attorney Tomasz Cyrol (Pedagogical University of Cracow, Poland) proves that

If the Hunting Law provides for a norm that allows for hunting, then it should be interpreted in such a way as not to infringe the welfare of animals, or more precisely - to infringe them to the smallest extent possible. This means that hunting, if it is to be allowed (...), should be carried out as a last resort, resulting from nature conservation objectives (Cyrol 2020, 33).

Cyrol analyses Polish legal acts concerning hunting and points to the absurdities found in them, such as the fact that the main goal is to protect animals while legitimizing their killing for trivial reasons. The Polish Constitution contains an order to protect the environment in several places. According to Cyrol, one may express doubts "as to whether the norm allowing hunting as a de facto form of entertainment is consistent with the fundamental law" (Cyrol 2020, 40). The regulations currently in force are contradictory, as hunting law is to be based on the protection of the natural environment (including animal welfare), which is denied by recreational hunting. It is also worth noting that, at the end of 2019, a law was passed in the Polish parliament stipulating a fine and imprisonment for obstructing hunting. People who actively represent the aversion to recreational hunting shared by the majority of society can expect punishment instead of appreciation and reward, and harassment instead of admiration for their steadfastness, dedication and courage.

Jedzok points out that the dialogue between hunters and the rest of the society faces many difficulties. The worldview and argumentation of hunters are based on a system of binary categories such as reason-emotions, man-woman, human-animal, or traditionmodernity. Despite increasing pressure from society, hunters are not considering eliminating recreational hunting. They do not attempt to radically reform the hitherto ruthless exploitation of the world of wild animals and limit themselves to observing it. It would be much more advantageous for the general public also in economic terms. In the United States, nature tourism brings in revenues $\$ 32$ billion (Jedzok 2020, 341).

Moreover, the artificial stimulation of natural growth by disproportionate feeding 
of animals by hunters harms the farmers. However, hobby hunters perceive criticism as a temporary image problem. That is why they make so much effort to ensure effective public relations. With the growing environmental awareness on the one hand and the ongoing urbanization of Europe on the other, it will be difficult to justify the practice of killing wild animals. Wildlife conservation will become imperative. This is an increasingly realistic forecast. Dąbek appeals: "Maybe we should give hunting a new meaning, adequate to modern times? Let the only trophy gained from tracking animals be beautiful photos or videos showing the life of these creatures in their natural environment. Such achievements can really be a manifestation of communing with nature, bringing with them an aesthetic and educational value" (Dąbek 2020, 95).

\section{Conclusions}

With numerous important and multifaceted contributions, the volume edited by Dorota Probucka should be studied by every person who is not indifferent to the fate of animals. The contributors examined the problem of hunting from various perspectives, using the rich scholarly literature in the field of law, ethics, psychology, cultural studies, sociology, linguistics and theology. They point out errors in reasoning and dichotomies in the arguments of hunting supporters, revealing the weakness of their narratives. Probucka convincingly proved that it is impossible to reconcile hunting with Christian religiosity. The very use of the figure of St. Hubert as the patron of the Polish Hunting Association is a great abuse and misunderstanding. At best, he could be "the spiritual guardian of only those hunters who have given up hunting practices" (Probucka 2020, 219).

Professor Halina Rarot (Lublin University of Technology, Poland), analysing the assumptions of the ethics of reverence for life (which precludes the idea of killing for pleasure), refers to the encyclical "Laudato si'” by Pope Francis and the writings of his great predecessor, St. Francis of Assisi. The trend of Christian eco-philosophy has been gaining more and more importance in recent times. All of us, regardless of our religion and beliefs, are responsible for the natural world and for preventing an ecological disaster. Fighting recreational hunting is part of this mission. Its success depends on many practical activities and our everyday attitudes. Philosophers can expose irrationalism and internal contradictions in the message of hunters, ethicists expose its hypocrisy, lawyers propose new solutions, teachers educate, and parents make their children sensitive to the fate of animals.

The volume also includes a substantive critique of the assumptions, goals and methods of implementing the hunting education program "Hunters for children, children for animals", and a whole series of critical references to the Code of Hunting Ethics presented by Marcin Urbaniak. The monograph also deals with the problem of the legal, ethical and psychological aspects of the participation of minors in hunting - most prominently, but not only - in the chapter by Beata Kulisiewicz (Jan Długosz University of 
Humanities in Częstochowa, Poland).

Dariusz Gzyra (Warsaw University, Poland), in turn, carries out a constructive and factual criticism of Miles Olson's hunting concept, while Justyna Tymieniecka-Suchanek (Silesia University in Katowice, Poland) discusses the beginnings of the anti-hunting movement in Russia. It should be emphasized at this point that the spiritual patron of the publication is Vladimir Borejko, a Ukrainian scientist, zoologist and nature protection activist, author of the work Quit Hunting - Become Human (published in 2005), which was the inspiration for the monograph.

It is difficult to deny the historical volatility of acceptable ethical standards. In the course of the development of moral awareness in recent decades, such as the fight against discrimination based on race, gender, sexual orientation or religion, we have come to understand that rituals and social customs can be changed, and that not all are worth maintaining. Some of them have been abandoned, others limited or modified. There is no reason why the celebration of atavistic practice should be considered more important than ethical sensitivity, ordering us to eliminate the unnecessary suffering of living creatures, mammals and birds who have no chance of survival, when confronted with a torturer equipped with weapons. They constitute living toys to shoot at.

Nature, if left undisturbed, is capable of self-regulation. The hunters armed with shotguns and other weapons could be replaced by natural hunters who, fortunately, pose no threat to humans. Meanwhile, accidents involving bystanders occur during hunting. Hunters pose a very real threat to other people, such as mushroom pickers, campers or tourists. Moreover, by persuading young people to participate in hunting, they accustom them to violence, for which no moral justification can be found.

If we were able to refrain from killing wolves and bison, we can also spare hares, deer and boars. If we can refrain from inflicting pain on living creatures who can feel it, we should try to spare them at all costs. This is an ethical imperative that precludes the endorsement of sporting game hunting. Such activities are an expression of human pride and a thirst for domination, channelling an aggressive drive that should be discharged in a cruelty-free manner.

There are different kinds of morals, not all of them righteous, some still accepting various forms of wickedness. An argument from empiricism cannot be the basis of ethical justification. Ethics makes sense as long as it clearly distinguishes between drives and inclinations and obligations, between what people actually do and what they should do. Immanuel Kant put forward convincing arguments in this regard a long time ago. Moral principles cannot be based on what some of us do when they follow their inclinations and take pleasure in it. As Leszek Kołakowski argued: "Our civilization would be in danger of disintegrating if we agreed that the criteria for distinguishing between good and evil cannot be determined at all, or worse, they can be deduced from actual human behaviour, from instincts" (Kołakowski 1990, 71). The fact that people enjoy certain actions does not make them morally justified. It does not matter how many people share similar 
preferences. As Dąbek notes: "An act is morally right because of the good that is present in it, and not because of common opinion or practice. The prevalence of a practice does not make it morally right and worth following because of it" (Dąbek 2020, 96). Probucka states in the same vein "the fact that a certain collective habit has been copied for generations does not imply the obligation to continue it" (Probucka 2020, 223).

Throughout history, the morality that legitimizes slavery, racial segregation and gender discrimination has been compromised. It is time to reveal the true nature of recreational hunting and the morals of hunters. It is based on hypocrisy. Hunters who present themselves as nature lovers see nature "as a resource and animals as a target, literally and figuratively" (Jedzok 2020, 88).

The masks are off, whoever has doubts can refer to the scholarly literature, and the discussed monograph is a rich source of scientific data.

The scientific part is supplemented with an essay by the precursor of one of the most important currents of ecological ethics - biocentrism, the former hunter Vladimir Chertkov, who set himself the goal of exposing the horror and brutality of hunting practices at a time when they were popular among the Russian elite. Chertkov successfully initiated the anti-hunting movement in Russia. His essay is preceded by a preface by Leo Tolstoy. The last part of the monograph contains excruciating excerpts from the book of Tomasz Matkowski entitled Polowaneczko (which is a thorough analysis of the mindset of hunters) and the book Farba znaczy krew [Engl. Paint Means Blood] authored by Zenon Kruczyński, a former hunter.

It also includes excerpts from the diary of Barbara Hartman (Cracow), an animal activist involved in numerous hunting protests. Direct accounts of witnesses give us an insight into the realities of the massacre of recreational hunting and allow us to learn the details, including the linguistic ones, that make up this ghastly ritual. Admittedly, these passages are difficult to read. At the end of the book a comprehensive list of Polish organizations and community groups condemning the hunting hobby and the participation of children in hunting can be found, thanks to which readers can gain knowledge about the scope of the anti-hunting movement in Poland.

\section{References}

Cyrol T. 2020. „Czy myślistwo rekreacyjne jest zgodne z prawem?” [Engl. Is recreational hunting lawful?], in D. Probucka (Ed.), Etyczne potępienie myślistwa [Engl. The ethical condemnation of hunting] (pp. 31-42). Kraków: Universitas.

Dąbek D. 2020. “O instrumentalnym traktowaniu etyki przez myśliwych” [Engl. On the instrumental treatment of ethics by hunters], in D. Probucka (Ed.), Etyczne potępienie myślistwa (pp. 91-105). Kraków: Universitas. 
Elżanowski A. 2002. „Prymitywizm motywacji do polowania” [Engl. The primitivism of being motivated for hunting], in D. Probucka (Ed.), Etyczne potępienie myślistwa (pp. 57-73). Kraków: Universitas.

Helios J. \& Jedlecka W. 2017. „Okrucieństwo wobec zwierząt z punktu widzenia psychologii i filozofii - zarys problemu" [Engl. Cruelty to animals from a psychological and philosophical view - an outline of the problem], Acta Universitatis Wratislaviensis 3759:31-44.

Jedzok D. 2002. „Zabójstwo z miłości. Kartezjańskie dychotomie w argumentacji zwolenników myślistwa rekreacyjnego" [Engl. Murder triggered by love. Cartesian dichotomies in the arguments of the supporters of recreational hunting], in D. Probucka (Ed.), Etyczne potępienie myślistwa (75-90). Kraków: Universitas.

Kołakowski L. 1990. Cywilizacja na ławie oskarżonych [Engl. Civilization in the dock]. Warsaw: Res Publica.

Korpikiewicz H. 2020. „Moje hobby: zabijanie” [Engl. My hobby: Killing], in D. Probucka (Ed.), Etyczne potępienie myślistwa (pp. 43-55). Kraków: Universitas.

Kruczyński Z. 2017. Farba znaczy krew [Engl. Paint means blood]. Wołowiec: Czarne Press.

Matkowski T. 2009. Polowaneczko [Engl. A sweet little hunting]. Warszawa: Nowy Świat Press.

Olson M. 2014. The Compassionate Hunter's Guidebook: Hunting from the Heart. New Society Publishers.

Plato 2008. Gorgias. Trans. B. Jovett. The Gutenberg Project (e-source, retrieved on December 25, 2020; https://www.gutenberg.org/files/1672/1672-h/1672-h. htm).

Plato 2007-2012. Crito. Trans. C. Woods \& B. Pack (e-source, retrieved on December 25, 2020; https://www.pitt.edu/ mthompso/readings/crito.pdf)

Probucka D. (Ed.) 2020. Etyczne potępienie myślistwa [Engl. Ethical condemnation of hunting]. Kraków: Universitas.

Probucka D. 2018a. “Ethical Condemnation of Recreational Hunting," Zoophilologica. Polish Journal of Animal Studies 4:141-147.

Probucka D. 2018b. "On the Concept of Ecological Solidarity. What Connects Animal Rights with the Rights of Human Beings?," Humanistyka \& Przyrodoznawstwo 24:39-47.

Probucka D. 2017. "European Philosophy and Its Negative Impact on the Treatment of Animals," Zoophilologica. Polish Journal of Animal Studies 3:155-162.

Skubała P. 2018. „Czy polowania w dzisiejszym świecie mają rację bytu?” [Engl. Do we need hunting in today's world?], Zoophilologica. Polish Journal of Animal Studies 4:105-119. 